\title{
Successful propagation of shrimp yellow head virus in immortal mosquito cells
}

\author{
Warachin Gangnonngiw ${ }^{1,2}$, Nipaporn Kanthong ${ }^{3}$, Timothy W. Flegel ${ }^{1,2,4, *}$ \\ ${ }^{1}$ Centex Shrimp, Faculty of Science, Mahidol University, Rama 6 Road, Bangkok 10400, Thailand \\ ${ }^{2}$ National Center for Genetic Engineering and Biotechnology (BIOTEC), National Science and Technology Development \\ Agency, Klong 1, Klong Luang, Pratum Thani 12120, Thailand \\ ${ }^{3}$ Dept. Biotechnology, Faculty of Science and Technology, Rajamangala University of Technology Tawan-ok, Sriracha, \\ Chonburi 20110, Thailand \\ ${ }^{4}$ Dept. Biotechnology, Faculty of Science, Mahidol University, Rama 6 Road, Bangkok 10400, Thailand
}

\begin{abstract}
Research on crustacean viruses is hampered by the lack of continuous cell lines susceptible to them. To overcome this problem, we previously challenged immortal mosquito and lepidopteran cell lines with shrimp yellow head virus (YHV), followed by serial, split-passage of whole cells, and showed that this produced cells that persistently expressed YHV antigens. To determine whether such insect cultures positive for YHV antigens could be used to infect shrimp Penaeus monodon with YHV, culture supernatants and whole-cell homogenates were used to challenge shrimp by injection. Shrimp injected with culture supernatants could not be infected. However, shrimp injection-challenged with whole-cell homogenates from Passage 5 (early-passage) of such cultures died with histological and clinical signs typical for yellow head disease (YHD), while homogenates of mock-passaged, YHV-challenged cells did not. By contrast, shrimp challenged with cell homogenates of late-passage cultures became infected with YHV, but survived, suggesting that YHV attenuation had occurred during its long-term serial passage in insect cells. Thus, YHV could be propagated successfully in C6/36 mosquito cells and used at low passage numbers as a source of inoculum to initiate lethal infections in shrimp. This partially solves the problem of lack of continuous shrimp cell lines for cultivation of YHV.
\end{abstract}

KEY WORDS: Shrimp $\cdot$ Virus $\cdot$ Insect cell line $\cdot$ YHV $\cdot$ Propagation

\section{INTRODUCTION}

Experimental work on shrimp and other crustacean viruses is hampered by the lack of a continuous cell line susceptible to them (Crane \& Benzie 1999). Our preliminary attempts to solve this problem by using insect cell lines (C6/36 mosquito cells and Sf9 lepidopteran cells) failed because viral passages were carried out using culture supernatant solutions to challenge succeeding batches of naïve insect cells (authors' unpubl. data). Our subsequent work with insect viruses revealed that persistent infections with 1 or 2 insect viruses could be simply achieved by serial split-pas- sage of whole cells (Burivong et al. 2004, Kanthong et al. 2008). When this technique was used with shrimp yellow head virus (YHV) and white spot syndrome virus (WSSV), both mosquito (C6/36) and lepidopteran (Sf9) cell lines were obtained that persistently expressed the appropriate viral antigens as those detected by confocal microscopy (Sriton et al. 2009). However, transmission electron microscopy did not show any recognizable viral particles of YHV or WSSV in the immunopositive insect cells, and no tests were carried out to establish whether the intact viral genomes of the 2 viruses were being replicated in the insect cells. To address this issue, we carried out 
shrimp Penaeus monodon challenge tests with inoculum prepared using YHV-immunopositive C6/36 cell cultures from early and late passages and monitored the shrimp for YHV infections by histology and immunohistochemistry.

As initially described from Thailand (Boonyaratpalin et al. 1993, Chantanachookin et al. 1993, Flegel et al. 1999, Flegel 2006), YHV is a lethal shrimp pathogen. However, several geographical types have now been described, and some of these are non-virulent or less virulent than the original type (Walker et al. 2002, Soowannayan et al. 2003, Wijegoonawardane et al. 2008). YHV is an enveloped, single-stranded, positive-sense RNA virus that is classified in a new family Roniviridae and genus Okavirus (Walker et al. 2005). Some work has been carried out with YHV in primary shrimp cell lines (Lu et al. 1995, Kasornchandra et al. 1999, Assavalapsakul et al. 2005, Tirasophon et al. 2005).

\section{MATERIALS AND METHODS}

Insect cell cultures. C6/36 mosquito cells (a single cell-type clone obtained from the American Type Culture Collection under catalogue number CRL-1660) were maintained in supplemented Leibovitz's (L-15) medium (Gibco Invitrogen) and persistently infected with YHV as previously described (Sriton et al. 2009). Briefly, this consisted of exposing the cells to YHV inoculum for $2 \mathrm{~h}$, followed by washing before addition of fresh culture medium. After incubation for $5 \mathrm{~d}$, cells were washed, suspended in fresh medium and transferred (1:3 split ratio) to a new culture dish. In addition to control cultures of naïve cells subjected to serial split-passage, a second YHV mock-passage, dilution control was also included. This consisted of C6/36 cells challenged with YHV in the same manner as the test cells, but immediately subjected to 5 mock, splitpassages by a 1:3 dilution with naïve C6/36 cells. This simulated the dilution of viral inoculum that would occur during the split-passage process for the test cells. Naïve control cells were mock-challenged with buffer and then subjected to serial split-passage in the same manner as the viral-challenged cells.

PCR and RT-PCR methods. RNA was extracted from at least $10^{6}$ infected cells or $1 \mathrm{ml}$ of culture supernatant medium using Trizol reagent (Invitrogen) following the protocol given by the manufacturer. Templates were adjusted to 100 ng RNA by spectrometry and used with 2 different RT-PCR protocols. One template previously described (Wongteerasupaya et al. 1997) gave an amplicon of $135 \mathrm{bp}$ from ORF1b of the YHV genome (positions 13831 to 13964 of GenBank EU487200). The other was designed based on the $277 \mathrm{bp}$ nested PCR product of the IQ 2000 test kit (Farming Intelligene) that is the specific amplicon for YHV Type 1 of the YHV complex; it targets positions 12864 to 13141 of GenBank EU487200 in the region of the overlap between ORF1a and 1b. The primers were GY2 (5' CAT CTG TCC AGA AGG CGT CTA TGA 3') and Y3 (5' ACG CTC TGT GAC AAG CAT GAA GTT 3') and the RT-PCR mixture contained $15.25 \mu \mathrm{l}$ of water, $5 \mu \mathrm{l}$ of $5 \times$ RT-PCR buffer (Roche), $1.25 \mu \mathrm{l}$ of $100 \mathrm{mM}$ DTT (Roche), $0.5 \mu \mathrm{l}$ of dNTP mixed, $0.25 \mu \mathrm{l}$ of $10 \mu \mathrm{M}$ primer GY2, $0.25 \mu$ l of $10 \mu \mathrm{M}$ primer Y3, $0.5 \mu \mathrm{l}$ of Titan enzyme and $2 \mu \mathrm{l}$ of template (total volume $=25 \mu \mathrm{l}$ ). The RTPCR protocol consisted of $50^{\circ} \mathrm{C}$ for $30 \mathrm{~min}$ and $94^{\circ} \mathrm{C}$ for $2 \mathrm{~min}$, followed by 35 cycles of $94^{\circ} \mathrm{C}$ for $20 \mathrm{~s}, 62^{\circ} \mathrm{C}$ for $20 \mathrm{~s}$ and $68^{\circ} \mathrm{C}$ for $30 \mathrm{~s}$, followed by an extension at $68^{\circ} \mathrm{C}$ for $10 \mathrm{~min}$ and cooling to $20^{\circ} \mathrm{C}$. When no positive amplicon was obtained with either method, $2 \mu \mathrm{l}$ from the first RT-PCR reaction vial was used as the template for a second RT-PCR reaction using the same primers and protocol as for the first reaction.

Shrimp challenge tests. For culture medium challenge tests, $5 \mathrm{ml}$ of supernatant culture medium from a Day 2 culture was filtered through a membrane filter with a $5 \mathrm{kDa}$ exclusion limit (Amicon Ultra, Millipore) until only $500 \mu \mathrm{l}$ remained (i.e. $10 \times$ concentration). This was injected intramuscularly at $100 \mu$ per shrimp at the fifth abdominal segment. For shrimp challenged with whole-cell homogenates of cultured insect cells, approximately $1 \times 10^{6}$ whole cells were collected and washed with phosphate-buffered saline (PBS) before being homogenized in $100 \mu \mathrm{l} \mathrm{L-15}$ using a sonicator (vibra cell) set at amplitude 50 for $30 \mathrm{~s}$. The homogenate was injected $\left(100 \mu \mathrm{lshrimp}^{-1}\right)$ directly (equivalent to approximately $10^{6}$ cells) or diluted by one-half in the same medium (equivalent to $5 \times 10^{5}$ cells) into the fifth abdominal segment. The shrimps Penaeus monodon (approximately 7 to $10 \mathrm{~g}$ each) were obtained from a local shrimp farm and held in $200 \mathrm{l}$ artificial seawater at $15 \mathrm{ppt}$ and at $28^{\circ} \mathrm{C}$ in a covered, outdoor wet laboratory. They were fed twice daily with a commercial shrimp feed, and excess feed was removed daily. Challenges were carried out after the shrimp had been acclimatized in the laboratory for $1 \mathrm{~d}$ (healthy shrimp). Before challenge, the shrimp were tested for absence of the challenge virus using the primers GY2 and Y3. The GY2 set is specific for both sub-types ( $a$ and b) of YHV Type 1 and does not give amplicons for the other types of YHV (Types 2, 3 and 5) previously reported from Thailand (Gangnonngiw et al. 2009).

Histological analysis of challenged shrimp. Hemolymph from challenged shrimp was collected in anticoagulant (called shrimp salt solution [SSS] containing $450 \mathrm{mM} \mathrm{NaCl}, 10 \mathrm{mM} \mathrm{KCl}, 10 \mathrm{mM}$ EDTA and $10 \mathrm{mM}$ HEPES) on Day 2 post-challenge, and cells were pelleted by centrifugation at $1000 \times g$ for $5 \mathrm{~min}$, followed by washing with L-15. Hemocytes were seeded on 
cover glasses and left to attach for $3 \mathrm{~h}$ at $27^{\circ} \mathrm{C}$ before fixation with $4 \%$ paraformaldehyde in PBS ( $\mathrm{pH} 7.3$ ) for 15 min. They were washed twice with PBS, permeabilized with $0.1 \%$ Triton X-100 for 5 min and blocked with $10 \%$ normal bovine serum. After incubation with primary antibody Y-19 against YHV nucleocapsid protein p20 (Sithigorngul et al. 2002) for $1 \mathrm{~h}$, they were washed with PBS containing $0.05 \%$ Tween 20 (PBS-T) and then incubated with GAM Alexa Flour 486 (Molecular probe) (1:500) for $30 \mathrm{~min}$ and washed with PBS-T for $5 \mathrm{~min}$. This was followed by a second fixation in $4 \%$ formaldehyde in PBS for $15 \mathrm{~min}$ and counterstaining with TO-Pro 3 (Molecular probe) (1:500) nuclear stain for $1 \mathrm{~h}$ before a final wash with PBS. The cells were then examined by confocal microscopy.

In addition to shrimp cells, whole moribund shrimp from the challenge tests were fixed with Davidson's fixative and processed for histological examination with hematoxylin and eosin staining as described by Bell \& Lightner (1988). Tissues were examined for typical signs of WSSV and YHV infection (Lightner 1996). Immunohistochemistry was used to confirm the infections as previously described (Anantasomboon et al. 2006, Chaivisuthangkura et al. 2006).

\section{RESULTS AND DISCUSSION}

\section{Persistent infections of $\mathrm{YHV}$ in $\mathrm{C6} / 36$ cells}

Using serial split-passage of whole C6/36 cells challenged with YHV, we successfully produced cultures with $100 \%$ YHV-immunopositive cells as previously described (Sriton et al. 2009). They were immunopositive with monoclonal antibodies against capsid protein p20 and envelope proteins gp64 and gp116. Of the types of YHV previously reported from Thailand (Types $1 \mathrm{a}$ and $1 \mathrm{~b}$, Type 2, Type 3 and a Type $1 \mathrm{~b} / 5$ recombinant) (Gangnonngiw et al. 2009), the monoclonal antibody (MAb) we used against gp116 (3-2B) is known to bind only to gp116 of YHV Type 1a (Soowannayan et al. 2003), the type present in the original inoculum used to infect the C6/36 cells. Additional analysis by RT-PCR using the GY2 and Y3 YHV-specific primers revealed that the cultures were positive for YHV (Fig. 1) only by double RT-PCR, indicating low viral loads. Use of the GY2 primers confirmed the presence of YHV Type 1, supporting the positive immunohistochemical result with the MAb also specific to gp116 of YHV Type 1a. Increasing the quantity of total RNA used for template beyond $300 \mathrm{ng}$ was not possible, since it led to negative RT-PCR results, even for samples spiked with YHV RNA. In contrast to whole cells, culture supernatant solutions were negative for YHV using the same RTPCR protocol, suggesting that YHV target material was

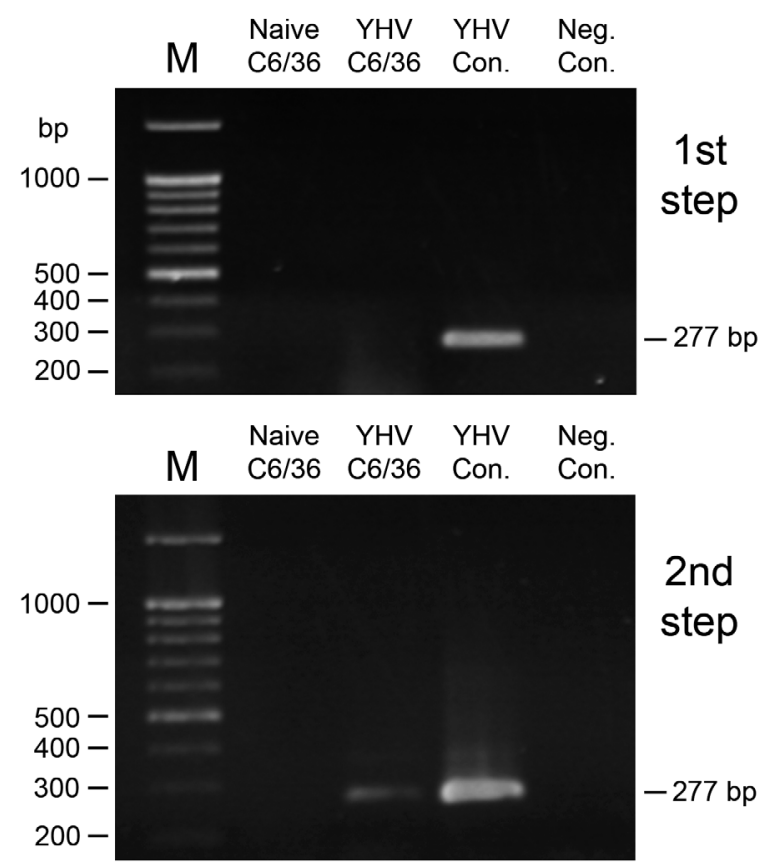

Fig. 1. Example photographs of agarose gels showing 2-step RT-PCR detection of yellow head virus (YHV) in naïve and YHV-immunopositive C6/36 cells. M: molecular marker; YHV Con.: positive control RNA template from YHV-infected shrimp; Neg. Con.: negative control distilled water template

not released into the culture medium, at least not in sufficient quantity to be detected by the methods used. This result corresponded to previous results showing a lack of recognizable YHV viral particles or nucleocapsids in YHV-imunopositive C6/36 cells by transmission electron microscopy (Sriton et al. 2009) and suggested that transmission of YHV in the insect cells most likely occurred during daughter cell production or by endocytosis.

\section{Challenge test results}

Challenge tests with inoculum prepared from concentrated culture supernatant solution failed to produce any shrimp Penaeus monodon mortality or signs of yellow head disease (YHD) (not shown). By contrast, shrimp injection with homogenates from YHVimmunopositive, whole-insect cells from Passage 5 led to $57 \%$ mortality at $2 \mathrm{~d}$ post-challenge when compared to no mortality for homogenates from naïve cells in the same interval. The diseased shrimp showed the typical histopathology associated with YHD (pyknotic and karryorrhectic nuclei in the lymphoid organ), and the cytoplasm of the relevant cells was positive for YHV by immunohistochemical analysis using MAbs to capsid protein p20 (Fig. 2b) and envelope protein gp116 


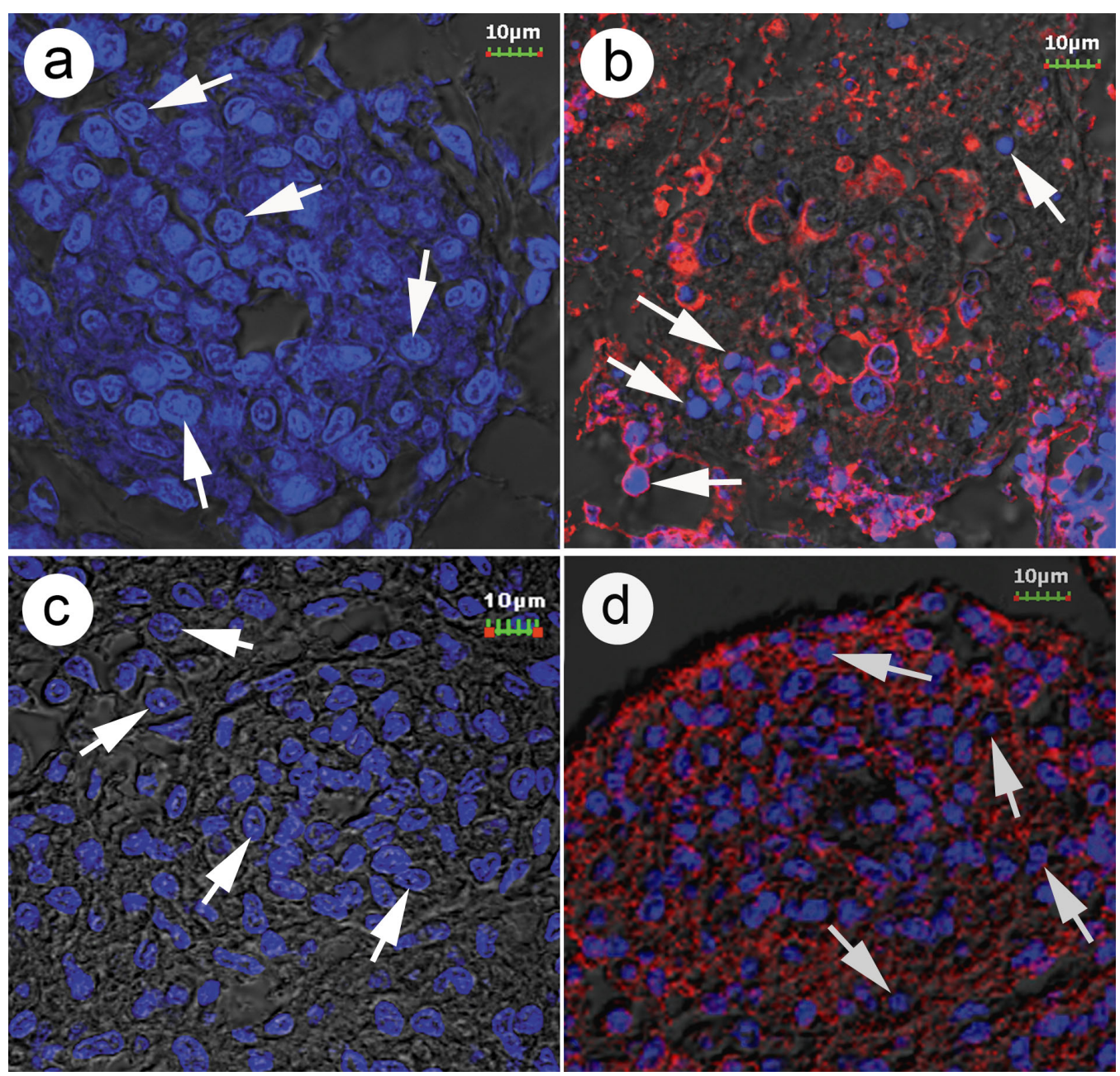

Fig. 2. Photomicrographs of lymphoid organ tissue from shrimp challenged with $(a, c)$ naïve C6/36 cell homogenate or (b,d) yellow head virus (YHV)-immunopositive C6/36 cell homogenates. Note intact nuclei (arrows) plus lack of immunoreactivity in the normal lymphoid organ tubules in (a) and (c). In contrast, (b) and (d) show pyknotic and karryorrhectic nuclei (arrows) characteristic of YHV infection plus immunopositive (red) cytoplasm for YHV, using monoclonal antibodies (MAbs) against (a) capsid protein p20 and (b) envelope protein gp116
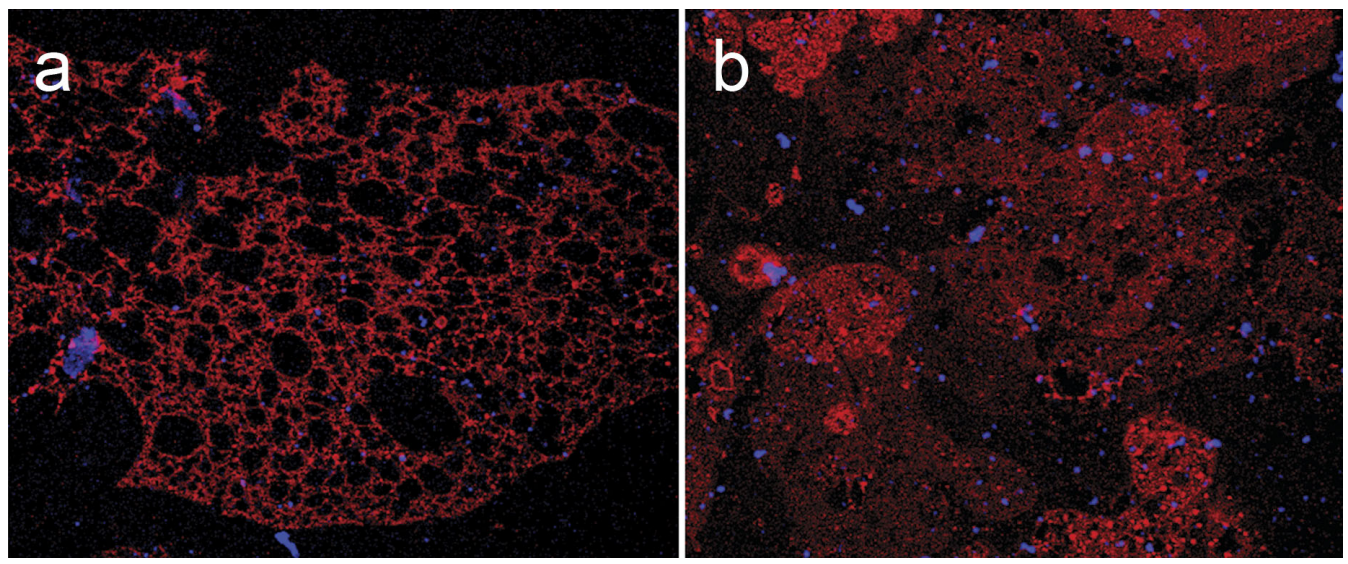

Fig. 3. Photomicrographs of immunocytochemical assays of (a) unboiled and (b) boiled homogenates of yellow head virus (YHV)immunopositive C6/36 cells (red) from Passage 5 

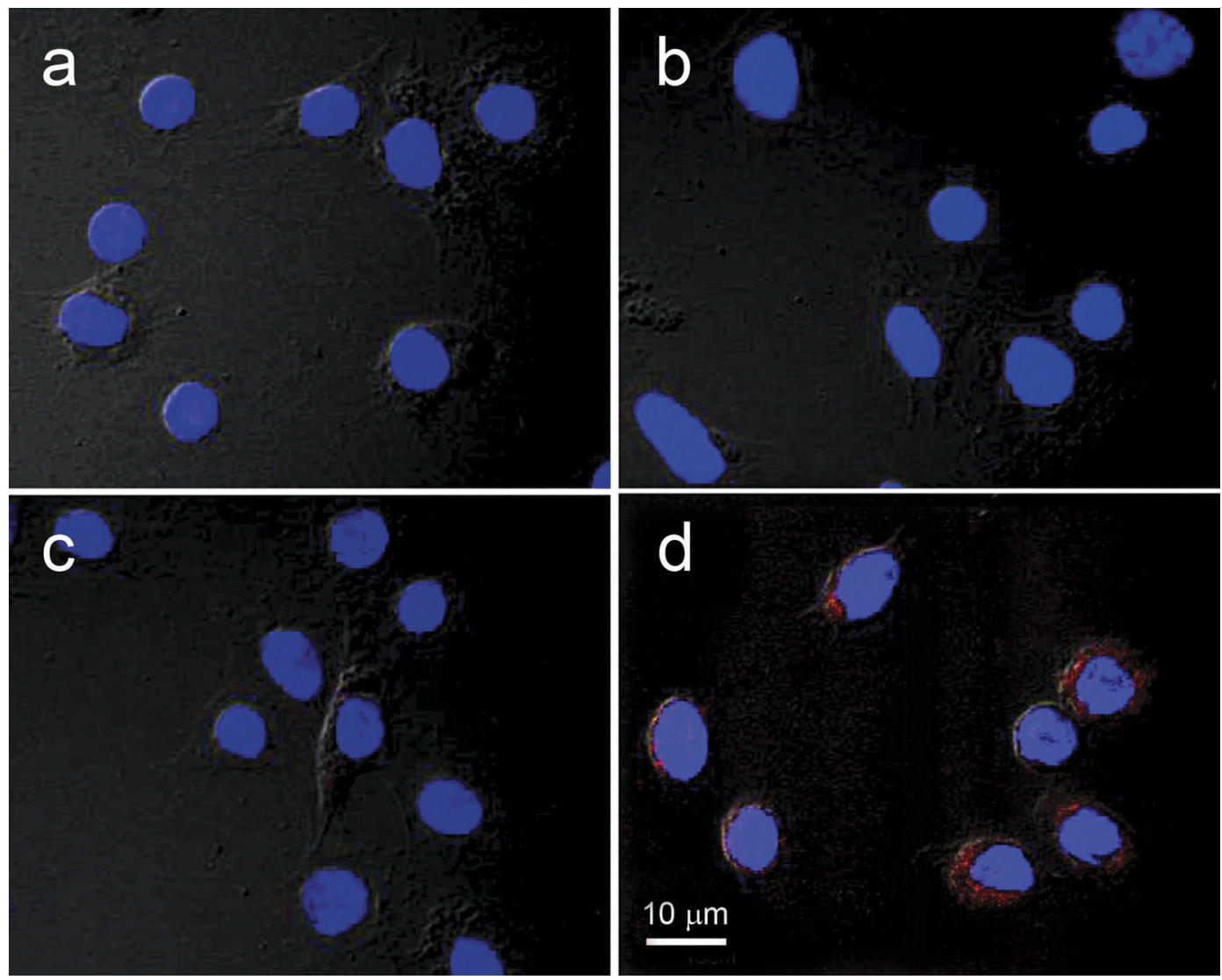

Fig. 4. Photomicrographs of hemocytes from normal shrimp and shrimp challenged with whole-cell homogenates of C6/36 cells and subjected to detection of yellow head virus (YHV) p20 capsid protein (red) and nucleic acid (blue) at $3 \mathrm{~d}$ post-challenge: challenged with (a) homogenate of naïve cells from Passage 5, (b) homogenates of YHV-challenged, mock-Passage-5 cells, (c) boiled homogenate of YHV-immunopositive cells from Passage 5 or (d) unboiled homogenate of YHV-immunopositive cells at Passage 5

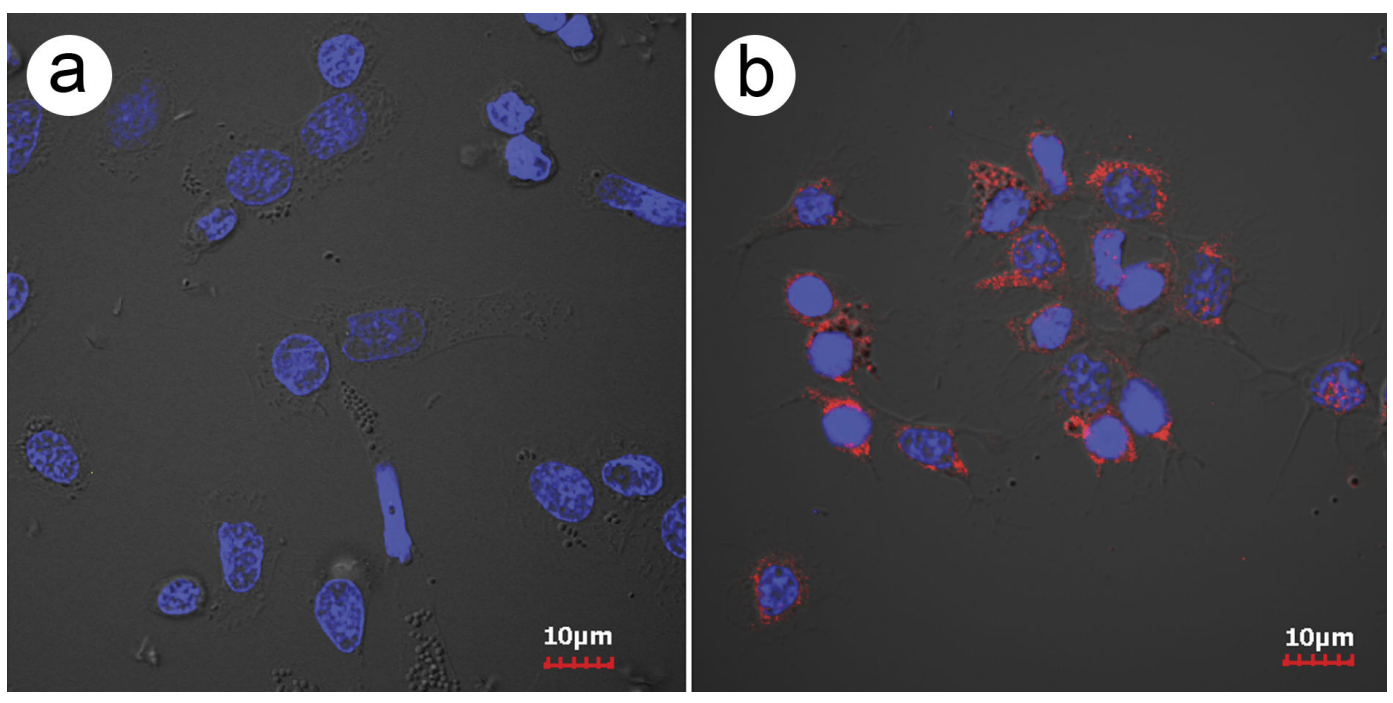

Fig. 5. Immunofluorescence photomicrographs of hemocytes from shrimp challenged with homogenates of either (a) whole naïve C6/36 cells or (b) whole yellow head virus (YHV)-immunopositive C6/36 cells from high Passage 27. The antibody used was anti-p20 capsid protein (which stained red) 
(Fig. 2d). As indicated above, the latter MAb is specific to gp116 of YHV Type 1a, the same type used to infect our C6/36 insect cells. The result for gp116 confirmed that the observed histological signs of YHD were not caused by other types of YHV (Types 2 and 3 and a Type 1b/5 recombinant) previously reported from Thailand, since they all give negative immunohistochemical results with this antibody and since they are also non-lethal to $P$. monodon (Soowannayan et al. 2003, Gangnonngiw et al. 2009). By contrast, neither shrimp mortality nor positive immunohistochemical reactions were observed in shrimp injected with homogenates of naïve C6/36 cells (Fig. 2a,c). Furthermore, the negative immunohistochemical reactions for p20 in the control shrimp (e.g. Fig. 2a) revealed that they were not infected with the other types of YHV known to occur in Thailand, nor did any immunopositive reactions result from injection of boiled homogenates of YHV-immunopositive cells from Passage $5\left(100^{\circ} \mathrm{C}\right.$ for $15 \mathrm{~min})$. An immunohistochemical test with the boiled and unboiled inoculum revealed that both were positive for YHV (Fig. 3), confirming that the boiled antigen was still immunoreactive. Similarly, C6/36 cells challenged with YHV and immediately subjected to serial dilution 5 times with fresh naïve cells (i.e. mock split-passage cells) did not lead to immunopositive hemocytes (Fig. 4). The lack of immunopositive hemocytes from the latter 2 tests confirmed that (1) YHVpositive immunofluorescence in hemocytes did not result from residual challenge virus but from infectious YHV that had replicated in the passaged insect cells; and (2) immunopositive hemocytes did not result from phagocytosis of injected YHV antigens but from antigens produced by infected hemocytes.

Some of the hemocytes in Figs. $3 \& 4$ show condensed nuclei that are normally characteristic of YHV infection. However, these occurred in both immunonegative hemocytes from the control shrimp and in immunopositive hemocytes and were a result of hemocyte changes during slide preparation for immunohistochemical analysis; they were not the result of YHV infection.

In contrast to homogenates from Passage 5, shrimp challenged with immunopositive whole-insect cells from Passage 27 did not lead to shrimp mortality or to the histopathology associated with YHD. However, confocal microscopy revealed the presence of hemocytes immunopositive for YHV capsid protein p20 (Fig. 5) and envelope protein gp64 (not shown). As described above (Fig. 4), these reactions did not result from phagocytosis of injected antigens, but from a replicative form of YHV that was present in the unboiled inoculum and that was transmitted to the shrimp hemocytes, where it replicated and produced YHV capsid protein and envelope protein. The advent of YHV infection, but lack of YHD, suggested that the late-passage, replicative form of YHV had become attenuated at high passage numbers.

This work revealed that YHV could be propagated successfully by serial split-passage of whole mosquito cells that showed no gross signs of infection. Although YHV was not released into the culture supernatant solution in detectable quantities, homogenates of whole cells from low passage numbers were capable of transmitting virulent YHV to challenged shrimp. Since the YHV-infected insect cells could be stored at $-80^{\circ} \mathrm{C}$ and revived when needed, the method will be useful for preservation and limited propagation of YHV. Although it is not proposed that these cultures should or would replace YHV extracts or purified YHV as inoculum for challenge tests with shrimp, the cultures might constitute a convenient, additional tool for laboratory studies on some topics, such as aspects of hostviral interaction and efficacy of double-stranded RNA constructs for knockdown of viral antigens. It remains to be determined whether homogenates of early passages of Sf9 cells persistently immunopositive for YHV antigens (Sriton et al. 2009) would also cause YHD in shrimp.

Acknowledgements. The present work was supported by Mahidol University and the Thai National Center for Genetic Engineering and Biotechnology (BIOTEC). The authors also thank Dr. Paisarn Sithigorngul of the Faculty of Science, Srinakharinwirot University, Bangkok, Thailand, for kindly providing the monoclonal antibodies for detection of YHV.

\section{LITERATURE CITED}

Anantasomboon G, Sriurairatana S, Flegel TW, Withyachumnarnkul B (2006) Unique lesions and viral-like particles found in growth retarded black tiger shrimp Penaeus monodon from East Africa. Aquaculture 253:197-203

Assavalapsakul W, Tirasophon W, Panyim S (2005) Antiserum to the gp116 glycoprotein of yellow head virus neutralizes infectivity in primary lymphoid organ cells of Penaeus monodon. Dis Aquat Org 63:85-88

Bell TA, Lightner DV (1988) A handbook of normal shrimp histology. World Aquaculture Society, Baton Rouge, LA

Boonyaratpalin S, Supamattaya K, Kasornchandra J, Direkbusaracom S, Ekpanithanpong U, Chantanachooklin C (1993) Non-occluded baculo-like virus, the causative agent of yellow head disease in the black tiger shrimp (Penaeus monodon). Fish Pathol 28:103-109

Burivong P, Pattanakitsakul SN, Thongrungkiat S, Malasit P, Flegel TW (2004) Markedly reduced severity of Dengue virus infection in mosquito cell cultures persistently infected with Aedes albopictus densovirus (AalDNV). Virology 329:261-269

> Chaivisuthangkura P, Phattanapaljltkul P, Thammapalerd N, Rukpratanporn S, Longyant S, Sithigomgul W, Sithigorngul P (2006) Production of polyclonal antibodies against recombinant VP26 structural protein of white spot syndrome virus (WSSV). ScienceAsia 32:201-204

Chantanachookin C, Boonyaratanapalin S, Kasornchandra J, Direkbusarakom S and others (1993) Histology and ultra- 
structure reveal a new granulosis-like virus in Penaeus monodon affected by yellow-head disease. Dis Aquat Org 17:145-157

> Crane MSJ, Benzie J (1999) The aquaculture CRC international workshop on invertebrate cell culture, 2-4 November 1997, University of Technology, Sydney, Australia. Methods Cell Sci 21:171-172

Flegel TW (2006) Detection of major penaeid shrimp viruses in Asia, a historical perspective with emphasis on Thailand. Aquaculture 258:1-33

Flegel TW, Thamavit V, Pasharawipas T, Alday-Sanz V (1999) Statistical correlation between severity of hepatopancreatic parvovirus infection and stunting of farmed black tiger shrimp (Penaeus monodon). Aquaculture 174: 197-206

- Gangnonngiw W, Anantasomboon G, Sang-oum W, Sriurairatana S, Sritunyalucksana K, Flegel TW (2009) Nonvirulence of a recombinant shrimp nidovirus is associated with its non structural gene sequence and not a large structural gene deletion. Virology 385:161-168

Kanthong N, Khemnu N, Sriurairatana S, Pattanakitsakul SN, Malasit P, Flegel TW (2008) Mosquito cells accommodate balanced, persistent co-infections with a densovirus and Dengue virus. Dev Comp Immunol 32: 1063-1075

Kasornchandra J, Khongpradit R, Ekpanithanpong U, Boonyaratpalin S (1999) Progress in the development of shrimp cell cultures in Thailand. Methods Cell Sci 21:231-235

Lightner DV (1996) A handbook of pathology and diagnostic procedures for diseases of penaeid shrimp. World Aquaculture Society, Baton Rouge, LA

Lu Y, Tapay LM, Loh PC, Brock JA, Gose R (1995) Development of a quantal assay in primary shrimp cell culture for yellow head baculovirus (YBV) of penaeid shrimp. J Virol Methods 52:231-236

Editorial responsibility: Grant Stentiford, Weymouth, UK
Sithigorngul P, Rukpratanporn S, Longyant S, Chaivisuthangkura P, Sithigorngul W, Menasveta P (2002) Monoclonal antibodies specific to yellow-head virus (YHV) of Penaeus monodon. Dis Aquat Org 49:71-76

Soowannayan C, Flegel TW, Sithigorngul P, Slater J and others (2003) Detection and differentiation of yellow head complex viruses using monoclonal antibodies. Dis Aquat Org 57:193-200

Sriton A, Khantong N, Gangnonngiw W, Sriurairatana S, Ubol S, Flegel TW (2009) Persistent expression of shrimp-virus antigens in 2 insect cell lines challenged with 2 shrimp viruses. Fish Pathol 44:86-93

Tirasophon W, Roshorm Y, Panyim S (2005) Silencing of yellow head virus replication in penaeid shrimp cells by dsRNA. Biochem Biophys Res Commun 334:102-107

Walker PJ, Phan T, Hodgson RAJ, Cowley JA, Flegel TW, Boonsaeng V, Withayachumnarnkul B (2002) Yellow head-complex viruses occur commonly in healthy P. monodon in Asia and Australia. In: World Aquaculture 2002. World Aquaculture Society, Beijing, p 773

Walker PJ, Bonami JR, Boonsaeng V, Chang PS and others (2005) Family Roniviridae. In: Fauquet CM, Mayo MA, Maniloff J, Desselberger U, Ball LA (eds) Virus taxonomy, VIIIth report of the ICTV. Elsevier/Academic Press, London, p 973-977

Wijegoonawardane PKM, Cowley JA, Phan T, Hodgson RAJ, Nielsen L, Kiatpathomchai W, Walker PJ (2008) Genetic diversity in the yellow head nidovirus complex. Virology 380:213-225

Wongteerasupaya C, Tongchuea W, Boonsaeng V, Panyim S, Tassanakajon A, Withyachumanarnkul B, Flegel TW (1997) Detection of yellow-head virus (YHV) of Penaeus monodon by RT-PCR amplification. Dis Aquat Org 31: 181-186

Submitted: September 28, 2009; Accepted: March 10, 2010 Proofs received from author(s): April 22, 2010 